\section{VANESSA JOOSEN ADULTHOOD IN CHILDREN'S LITERATURE} London: Bloomsbury, 2018 (243 s.)

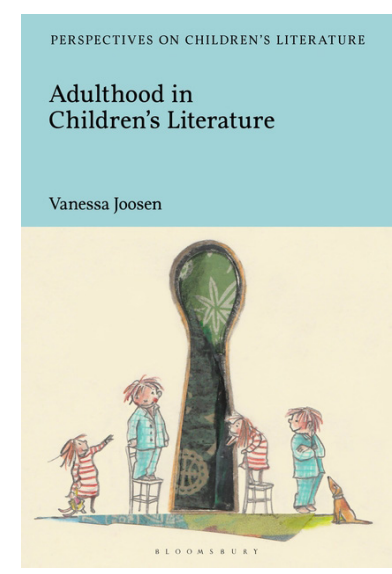

Traditionellt sett har det varit de "avvikande" som undersökts, beskrivits och förklarats - exempelvis kvinnor, homosexuella och icke-vita, men även barn. På samma sätt som feminismen, queerteorier och postkoloniala studier senare vänt på blicken och avslöjat det "normala" som minst lika specifikt och godtyckligt konstruerat, har kritiska åldersstudier visat på vuxenhet som en osynlig norm och ett "neutralt" utgångsläge i västvärlden. Till skillnad mot barndom och ålderdom definierades den vuxna åldern inte medicinskt förrän mot slutet av 1900-talet (10), konstaterar Vanessa Joosen i sin nya studie Adulthood in Children's Literature. Ordet som används i boken är engelskans "adulthood", men det är talande att det i det svenska språket inte finns någon likvärdig översättning, motsvarande begreppen barndom och ålderdom.

Inom barnlitteraturforskning är det som bekant vanligt att barn och barndomen står i fokus. Joosen vill med denna monografi tillämpa insikter och begrepp från kritiska åldersstudier för att istället rikta blicken mot hur vuxenliv skildras i barnböcker. Utgångspunkten är ålder som social konstruktion och maktordning. Joosen menar att skildringar av vuxen ålder är särskilt intressanta att studera i barnböcker, då de ofta är den första litteratur som barn kommer i kontakt med, men också läses av föräldrar och andra vuxna. Dessa dubbla adressater gör att konstruktionen av vuxenliv i barnböcker både kan bidra till barns ålderssocialisation och till den vuxna läsarens förståelse av vuxenhet som levd erfarenhet. 
Boken rymmer sex kapitel som alla berör olika aspekter av vuxenhet i barnböcker. Urvalet består främst av böcker som riktar sig till barn upp till 12 år, är utgivna från 1970 och framåt, och har blivit nominerade till eller belönade med litterära priser i Nederländerna eller Storbritannien. Dessa kriterier gör dock Joosen flera avsteg ifrån, då hon drivs av en vilja att visa på tendenser och trender, men också avvikelser från dem. Av intresse är verk som Joosen menar tematiserar vuxen ålder, och analyserna baserar sig på metareflektioner om vuxenhet eller beteenden hos karaktärer som identifieras som vuxna.

Joosen tillämpar i sina analyser semiotiska och mimetiska läsningar om vartannat. Detta då hon framhäver att ålderskonstruktioner visserligen är baserade på levda erfarenheter, men att skildringarna också är styrda av hänsyn till narrativ och genre. Detta utgör en givande och sympatisk metod, där Joosen ofta går i dialog med sig själv om olika tolkningsmöjligheter, och är uppmärksam på hur verken kan förmedla existerande åldersnormer och ideologier, men också visar en känslighet för att texterna är litterära verk konstruerade av vuxna författare.

Joosens grundläggande tes presenteras direkt i introduktionen. Bilden av två barn som kikar in på sina föräldrar genom ett nyckelhål, vilken pryder monografins omslag och som hämtats från Marita De Sterck och An Candaeles bilderbok Koekeloeren (2008), beskrivs som en metafor för hur vuxenlivet skildras i barnböcker. Detta menar hon präglas av "blind space", då kunskapen om, och ofta även bildligt talat synen på, de vuxnas liv begränsas. Termen kommer ursprungligen från filmstudier, men applicerades på barnlitteratur i Alice Currys "The 'Blind Space' that Lies Beyond the Frame" (2010). Att saker utelämnas eller döljs kan ses som en följd av att barnböcker ofta använder sig av ett barn som fokalisator, men också som ett aktivt val från författaren för att frånhålla viss kunskap från barnläsaren, antingen för att det ses som ointressant eller som opassande för barn.

Att veta eller inte veta placerar Joosen in i ett maktsystem, där vuxna innehar platsen högst upp i kunskapshierarkin. Här blir det återigen intressant med barnbokens dubbla adressater då författarens frånhållande av kunskap, som förefaller självklar för vuxna, kan skapa en ironisk distans mellan den vuxna läsaren och barnfokalisatorn. Joosen förespråkar istället barnböcker som ger barn insikt i vuxnas angelägenheter, och vuxna en större förståelse för barns perspektiv. Många barnböcker rymmer didaktiska budskap, men Joosen påvisar att dessa inte enbart riktar sig till barnen, utan ofta även handlar om att vara goda föräldrar och vuxna, genom att respektera och lära sig av barn. 
I det första analyskapitlet söker Joosen definiera hur vuxen ålder skildras i barnböcker. Hon undersöker här vilka teoretiska perspektiv från kritiska åldersstudier som kan vara tillämpbara, och analyserar litteratur som diskuterar eller tematiserar åldersnormer. Joosen identifierar här två motsatta hållningar till gränsen mellan barndom och vuxenliv bland forskare, dels de som vill överskrida denna gräns genom att betona gemensamma mänskliga drag, dels de som vill förstärka gränsen och "låta barn vara barn", genom att begränsa vilken kunskap som de får tillgång till. Bilden av nyckelhålet får här även symbolisera gränsen mellan barndom och vuxenliv.

Joosen visar i sina analyser hur såväl författare som karaktärer i böckerna demonstrerar dessa två hållningar. Hon menar nämligen att vuxna kan fungera antingen som "enablers" eller "gatekeepers" i relation till barn, genom att stödja eller hindra deras lärande. Författare gör detta genom att behandla eller utesluta känslig kunskap i verken, och de vuxna karaktärerna genom att uppmuntra nyfikenhet och lärande eller lydighet och underdånighet hos barnkaraktärerna. Joosen ger här även exempel på ett flertal böcker som dekonstruerar denna gräns och visar på något av komplexiteten i hur ålder tolkas och upplevs. Även i dessa böcker framstår dock en brist på självbehärskning och ansvarskänsla hos vuxna som negativt, speciellt om de är föräldrar.

Kapitel två behandlar vuxna protagonister, exempelvis Hugh Loftings Doktor Dolittle. Vanligt bland sådana sägs vara att de har alla friheter, men få eller inga av de förpliktelser som förknippas med vuxenhet - såsom jobb, eget boende eller familj. Dessa karaktärer uppfattas ofta som barnsliga, i positiv och romantiskt oskyldig bemärkelse, exempelvis genom sin nära kontakt med djur. Att blanda karaktärsdrag som förknippas med vuxna respektive barn kan sägas destabilisera åldersnormer och distinktionen mellan barn och vuxna, genom att visa på ett alternativ till att växa upp - att växa sidledes. Detta synes dock inte vara förenligt med reproduktion, och i de fall dessa barnlika karaktärer har egna barn ställer sig läsarna ofta kritiska till deras ansvarslöshet.

I kapitel tre är det den vuxna kroppens tur att undersökas, framförallt dess hårighet. Joosen visar här på en trend att nedvärdera och håna den vuxna kroppen, och än mer den åldrade, där hår tränger fram ur öron, näsor och mest överallt förutom på huvudet. Hår och pubertet framställs som något fult, äckligt och djuriskt - något som måste hållas i schack, trimmas och döljas. Denna ibland groteska nedvärdering av den vuxna kroppen förstår Joosen som del i en karnevalisk impuls, vilken vänder på maktförhållandena mellan barn 
och vuxna. Detta är dock tillfälligt, och bidrar snarare till att upprätthålla hierarkierna genom att söka bevara barns oskyldighet, och lär dem dessutom att skämmas för och disciplinera den egna kroppen.

Kapitel fyra behandlar "childism", Elisabeth Young-Bruehls term för diskriminering av barn. Termen används för att beskriva vuxna som ser sig som överlägsna barn, och betraktar dem som fiender eller osynliga "pseudovarelser". Detta tar sig uttryck i karaktärer som hotar, skadar eller manipulerar barn efter sina egna behov. Dessa karaktärer är vanliga som katalysatorer i barnböcker, exempelvis greve Olaf i pseudonymen Lemony Snickets Syskonen Baudelaires olycksaliga liv (1999-2006). Vanliga tecken på childism sägs vara att karaktärerna nedvärderar barnlitteratur, och att de dricker alkohol. Ofta rymmer böckerna även motparter till dessa karaktärer - vuxna som "hållit barnet inom sig levande", uppmuntrar barn till att berätta, läsa och skriva, och dricker saft eller varm choklad.

Dessa sympatiska, nyktra vuxna anknyter till nästa kapitel, som berör skildringar av vuxna författare. Joosen fokuserar här främst på fyra barnböcker av två olika författare, nämligen Guus Kuijers Tin Coincidence and the Art of Madelief (1989) och The Book of Everything (2004), samt Jacqueline Wilsons The Story of Tracy Beaker (1991) och Clean Break (2005). Alla fyra böcker rymmer en karaktär som är möjlig att se som författarens alter ego, men även en läsande och skrivande ung huvudperson. Författarna presenteras här som speciella vuxna och barnens allierade, inte minst genom att uppmuntra deras skrivande. Joosen lyfter fram de faktiska författarnas kommersiella intresse för att visa på deras bevarade barnslighet och engagemang för barns perspektiv som ett tecken på trovärdighet. Hon visar även hur böckerna rymmer svar på medial kritik mot författarna, medan frågor om deras faktiska skrivande lämnas åt böckernas blind space.

I det avslutande kapitlet handlar det om ålderdomen. Joosen menar att den i stort utplånats från media, och i övrigt präglas av ett narrativ om nedgång och förfall, sjukdom och förlust. Detta narrativ är förekommande även i barnböcker, men Joosen lyfter fram ett flertal titlar som motverkar detta. Istället framställs ålderdomen i positiv dager, som en tid för frihet, lycka och idealism - till skillnad mot vuxenålderns stress. De gamla framstår som allierade till barn, och de två åldersgrupperna tillägnas ofta samma fyra karaktärsdrag: en vilja till lek, en förkärlek för berättelser, ett intresse för det förflutna, och ett stort patos mot orättvisor (189).

Joosen lyfter även fram kritiska perspektiv från åldersstudier som komplicerar denna uppfattade positiva bild av äldre. Här finner man invändningar mot infantiliseringen av äldre människor, stereotypen 
av den visa mentorn som inte har något bättre för sig än att ställa upp på barnens alla behov, förnekandet av hög ålder och avsexualiseringen av äldre. Denna komplicering av ålderdomen synes dock inte Joosen ta på så stort allvar - avslutningen ägnas nämligen åt att varna för en gungbrädeeffekt. Hon menar att det i barnböckerna sker en uppvärdering av ålderdomen på bekostnad av vuxenlivet, som får ta över nedgångsnarrativet. Joosen efterfrågar barnböcker som kan motverka detta genom att lyfta fram positiva och njutbara aspekter av vuxenhet, och visa på en än större diversitet av hur ålder upplevs.

Adulthood in Children's Literature imponerar och inspirerar med sin mångfald av material, teoretiska utgångspunkter och insikter, och inte minst sin glädje inför barnlitteraturens rikedom. Detta är dock inte utan sina problem. De generöst tilltagna urvalskriterierna menar Joosen möjliggör jämföranden över tid och rum, men detta är endast sporadiskt genomfört. Mängden av böcker behandlas eklektiskt och ofta kortfattat, och Joosen gör som sagt ofta avsteg från kriterierna genom att lyfta in böcker från andra länder, tider och åldersmålgrupper. Detta ger ibland känslan av att tesen föregår materialet, och det blir svårt att dra några underbyggda slutsatser om hur vuxenhet skildrats under olika tider, i de olika länderna eller riktat till olika åldersgrupper.

Ibland går Joosen dessutom extra fort fram, exempelvis i kapitlet om håriga kroppar, då hon i ett stycke påstår att positiva skildringar av vuxnas kroppar kan peka på pedofili. Som exempel ges den nederländska författaren och dömda pedofilen Gie Laenen, som sägs ha använt barnböcker som en form av "grooming" (109). Joosen påpekar sedan visserligen att även hånandet av vuxna kroppar kan ses som en form av pedofili, i och med att det hyllar den hårlösa barnkroppen, men det känns slarvigt och alarmistiskt att i förbifarten lyfta fram ett enstaka exempel på en bok som inte hånar den vuxna kroppen och likställa det med (genomförd) pedofili utan vidare diskussion eller nyansering.

Även användningen av teoretiska perspektiv från kritiska åldersstudier hade tjänat på en mer genomgripande systematik. Joosen visar på ett flertal begrepp och förståelsemodeller som är möjliga att applicera i barnlitteraturforskningen, samtidigt som hon genom sitt insisterande på "blind spaces" som det avgörande för skildringen av vuxenhet i barnböcker förefaller likställa ålder som ordnande princip med kunskap som maktordning. Detta leder till den återkommande generaliseringen att vuxna vet och barn inte vet, trots att även vuxenlitteratur innehåller luckor och att mycket av det som Joosen menar att barnlitteraturen undanhåller från barn är okänt 
även för de flesta vuxna - exempelvis hur man skriver en skönlitterär bok eller hur det är att förlora ett barn.

Att det sista kapitlet handlar om ålderdom och barndom, trots den uttalade fokuseringen av vuxen ålder, visar på hur svårt det är att separera de olika kategorierna från varandra, då de hela tiden konstituerar varandra. Att sätta just den vuxna åldern i fokus kan visserligen tjäna till att synliggöra vuxennormativitet, men om man på allvar vill ifrågasätta ålderskategorierna tror jag att man behöver ta ett grepp om ålder som spektrum, och som en maktordning bland andra.

Detta är en bok som vill mycket. Det som saknas i metodisk rigiditet tar Joosen igen i kreativitet, bredd och skärpa. Mina invändningar till trots är detta passande kvaliteter för en bok som syftar till att öppna upp nya perspektiv, och som erbjuder en mängd uppslag att bygga vidare på.

Louise Almqvist Doktorand vid Institutionen för kultur-och medievetenskaper Umeå universitet 